Summer 8-1-2020

\title{
Temporary Protection Status: A Yugoslavian Precedent
}

\author{
Medina Dzubur \\ Indiana University Maurer School of Law, mdzubur@iu.edu
}

Follow this and additional works at: https://www.repository.law.indiana.edu/ijgls

Part of the Comparative and Foreign Law Commons, Law and Gender Commons, Law and Race Commons, Law and Society Commons, Military, War, and Peace Commons, and the Religion Law Commons

\section{Recommended Citation}

Dzubur, Medina (2020) "Temporary Protection Status: A Yugoslavian Precedent," Indiana Journal of Global Legal Studies: Vol. 27 : Iss. 2 , Article 9.

Available at: https://www.repository.law.indiana.edu/ijgls/vol27/iss2/9

This Article is brought to you for free and open access by the Law School Journals at Digital Repository @ Maurer Law. It has been accepted for inclusion in Indiana Journal of Global Legal Studies by an authorized editor of Digital Repository @ Maurer Law. For more information, please contact rvaughan@indiana.edu.

\section{$\Psi$}

JEROME HALL LAW LIBRARY

INDIANA UNIVERSITY

Maurer School of Law
Bloomington 


\title{
Passport to Plastics: Cosmetic Surgery Tourism, Medical Malpractice, and the Automatic Establishment of Personal Jurisdiction by Way of the Joint Commission International*
}

\author{
ELIZABETH ASTRUP ${ }^{\dagger}$
}

\section{INTRODUCTION}

For centuries, tourists have visited lands near and far in search of experiences unavailable in their home countries. ${ }^{1}$ From golfing the best courses in the world, to yoga retreats in remote locations, many tourist activities provide experiential opportunities along with health and wellness benefits. Currently, an increasing number of individuals are opting to cross international borders to receive medical treatments, often at reduced costs. ${ }^{2}$ While many scholars use the term health tourism to encompass all health and wellness travel purposes, ${ }^{3}$ this note uses the term medical tourism to distinguish tourism for the specific purpose of medical treatments or procedures. Medical tourism is

\footnotetext{
* The purpose of this note is not to debate the morality of cosmetic surgery or benefits and disadvantages of medical tourism in general, nor is it about gender dynamics, ethics, power imbalances, or socioeconomic status. Rather, the purpose of this note is to propose the establishment of new avenues that would allow medical tourists to recover easily in the event of medical malpractice abroad. All dollar amounts discussed are in USD.
}

† J.D. Candidate, 2020, Indiana University Maurer School of Law-Bloomington; B.A. in Political Science, 2017, Indiana University-Bloomington. I would like to thank Dr. Jody L. Madeira, whose seminar and guidance inspired this note.

1. See generally History of the Vacation, TRAVELEX, https://www.travelex.com /travelex-hub/travel-inspiration/history-of-the-vacation (last visited Oct. 10, 2018) (providing a historical analysis of tourism).

2. See Edward Kelley, Medical Tourism, World Health ORGanIZATION 3-6, 11 (Oct. 2, 2013), http://www.who.int/global_health_histories/seminars/kelley_presentation_ medical_tourism.pdf.

3. See Anna García-Altés, The Development of Health Tourism Services, 32 ANNALs oF TOURISM RESEARCH 262, 262 (2005).

Indiana Journal of Global Legal Studies Vol. 27 \#2 (Spring 2020)

(c) Indiana University Maurer School of Law 
considered one of the fastest-growing tourism sectors and is creating significant growth in economies across the globe. ${ }^{4}$

Like other developing areas of study, initial studies have only scratched the surface of medical tourism. Rather than analyzing these trends from a different perspective, this note draws on patterns from various nations to propose new methods of protecting patient rights, namely the right to sue in the event of medical malpractice abroad. Specifically, this note will propose the establishment of personal jurisdiction over accredited international healthcare facilities by way of an accrediting US organization. Part I will discuss the origins of medical tourism, explain how and why medical tourism became a booming industry, explore the intersection of medical tourism and medical malpractice, and discuss general principles of jurisdiction. Part II will analyze and compare policies from around the world-including the United States, Brazil, South Korea, and Thailand-concerning medical tourism, cosmetic surgery, and medical malpractice litigation. And finally, Part III will analyze the benefits of and advocate for Joint Commission International (JCI) accreditation, automatically establishing personal jurisdiction over foreign health care providers and facilities for litigants to bring suit in the United States; then provide a secondary proposal of the JCI serving as an appeals board for medical malpractice claims occurring at JCI-accredited healthcare providers.

\section{AN OVERVIEW OF MEDICAL TOURISM}

This section aims to provide a 10,000 -foot view of the medical tourism industry's complexities by discussing the origin and history of medical tourism, general principles of medical malpractice claims as they relate to cosmetic surgery and medical tourism, and jurisdictional problems relating to medical malpractice litigation. This note details these issues before delving into current policies and trends in medical tourism, cosmetic surgery, and medical malpractice litigation worldwide.

\section{History of Medical Tourism}

- Medical tourism is not a new fad. Around $70 \mathrm{AD}$, the Romans built a reservoir, a series of baths, and a temple around Aquae Sulis in

4. Methawee Wongkit \& Bob McKercher, Desired Attributes of Medical Treatment and Medical Service Providers: A Case Study of Medical Tourism in Thailand, 33 J. TRAVEL \& TOURISM MARKETING 14, 14 (2016). 
present-day Bath, England. ${ }^{5}$ These structures indicate that the baths were meant to serve healing purposes rather than mere relaxation. ${ }^{6}$ The baths still attract tourists from all over the world, even after nearly two thousand years. Moreover, in the eighteenth and nineteenth centuries, Europeans and Americans alike traveled to remote destinations in search of treatments for common deadly diseases such as tuberculosis. ${ }^{7}$ More recently, Americans have crossed borders to obtain certain medications at reduced costs. ${ }^{8}$ Alternatively, individuals living abroad have flocked to the United States to seek treatment for several reasons, including state-of-the-art facilities, a dependable accreditation system, and medical professionals that have been trained within the United States. ${ }^{9}$

The phenomenon of traveling abroad for surgery, however, is fairly new and becoming increasingly common. As the market for medical tourism has expanded, patients across the globe have opted to hop on planes, trains, and ships to seek care in other nations for a variety of reasons. Numerous medical tourism firms essentially travel agencies that coordinate medical procedures abroad for travelers-have made the process of seeking and obtaining care easier. ${ }^{10}$ In 2017 , more than 1.4 million Americans traveled to a different country for medical treatment, while the overall number of medical tourists worldwide was estimated to be somewhere between 14 and 16 million. ${ }^{11}$ As healthcare costs continue to rise in the United States, American patients travel abroad for significant cost-savings on medical procedures. ${ }^{12}$ For example, a tummy tuck, which costs an estimated $\$ 6,400$ in the United States, only

5. Spa Heritage, VISIT BATH, https//visitbath.co.uk/things-to-do/spa-andwellbeing/spa-heritage/ (last visited Oct. 10, 2018) ("A temple to Aesculopius ... provides a clue to there being a bath dedicated to healing, not just to relaxation.").

6. Id.

7. Kate Pickert, A Brief History of Medical Tourism, TIME (Nov. 25, 2008), http://content.time.com/time/health/article/0,8599,1861919,00.html.

8. For a discussion on the staggering difference in price for medications in the United States versus Canada, see Dan Mangan, Patients Cross Borders for Online Deals on Medications, CNBC (May 23, 2014, 1:44 PM), https://www.cnbc.com/2014/05/23/patientscross-borders-for-online-deals-on-medications.html.

9. Rebecca Bennie, Medical Tourism: A Look at How Medical Outsourcing Can Reshape Healthcare, 49 TEX. INT'L L. J. 583, 587 (2014).

10. See How the Medical-Tourism Business Thrives, THE ECONOMIST (July 28, 2018), https://www.economist.com/business/2018/07/28/how-the-medical-tourism-businessthrives.

11. James E. Dalen \& Joseph S. Alpert, Commentary, Medical Tourists: Incoming and Outgoing, 132 AM. J. MED. 9, 9 (2019).

12. Id. ("Because [the United States] ha[s] the most expensive health care system in the world, it is not difficult to find countries that offer various procedures at $30 \%-65 \%$ of the cost of care in the United States."). 
costs $\$ 2,900$ in India. ${ }^{13}$ On the other hand, significant innovation in medical science and technology draws foreign patients to the United States in search of cutting-edge techniques and quality care. ${ }^{14} \mathrm{~A}$ specific physician's reputation, the quality of a particular healthcare facility, and shortened wait times are reasons that all, when compared to cost, motivate individuals to travel abroad for a medical procedure. ${ }^{15}$

Within the United States, an independent, not-for-profit organization called the Joint Commission (JC) accredits and certifies domestic healthcare facilities and programs. ${ }^{16}$ Since its founding in 1951, the "Joint Commission accreditation and certification [has been] recognized nationwide as a symbol of quality that reflects an organization's commitment to meeting certain performance standards." 17 In order to maintain JC accreditation, known as the "Gold Seal of Approval," facilities must undergo and pass an on-site survey conducted by a team of JC surveyors every three years. ${ }^{18}$ To date, the $\mathrm{JC}$ has accredited or certified over 22,000 healthcare organizations and programs in the United States, ${ }^{19}$ and has accredited around 77 percent of US hospitals. ${ }^{20}$

Beginning in the late 1990s, JCI, effectively the "global arm of the Joint Commission," began to evaluate and accredit medical facilities around the world. ${ }^{21}$ For an international hospital to receive JCI accreditation, it must meet the same standards set forth by the $\mathrm{JC}$ in the United States. ${ }^{22}$ To date, there are more than 950 JCI-accredited

13. I. GlenN COHEN, PATIENTs with PASSPORTs: Medical TOURISM, LAW, AND ETHICS 1,4 (2015).

14. Id.

15. Id. at 6 .

16. About the Joint Commission, THE JOINT COMMISSION, https://www.joint commission.org/about_us/about_the_joint_commission_main.aspx (last visited Nov. 23, 2018) (facilities that can earn JC accreditation include hospitals [general, psychiatric, pediatric, and rehabilitative], dental and medical practices, dialysis centers, imaging centers, and nursing homes, among others).

17. $I d$.

18. Facts about the Joint Commission, THE JoINT COMMISSION (Apr. 12, 2019), https://www.jointcommission.org/facts_about_the_joint_commission/ (Note: compared to surveying all other facilities every three years, the JC surveys laboratories every two years).

19. Id.

20. Facts about Hospital Accreditation, THE JoINT COMMISSION (Sept. 12, 2018), https://www.jointcommission.org/accreditation/accreditation_main.aspx (follow the "Facts about Hospital Accreditation" link under "Accreditation Program Fact Sheets").

21. Jennifer B. Boyd et al., Emerging Trends in the Outsourcing of Medical and Surgical Care, 146 ARCH SURG. 107, 107 (2011).

22. Medical Tourism Statistics \& Facts, PATIENTS BEYOND BORDERS, https://patientsbeyondborders.com/medical-tourism-statistics-facts (last updated Jan. 15, 2019). 
medical institutions worldwide. ${ }^{23}$ While JCI accreditation makes patients confident that their chosen international healthcare provider is regularly monitored and held to higher standards, healthcare facilities are not required to be accredited. ${ }^{24}$ Hundreds of non-JCI-accredited hospitals and clinics around the world continue to operate and provide services to international patients. ${ }^{25}$ Apart from the JCI, the European Union also regulates medical facilities within member countries; otherwise, medical tourism remains "regulated only to the extent that the medical practice in individual countries is regulated." 26

\section{Medical Tourism and Malpractice}

Though few patients anticipate the worst when they seek medical care, patients traveling abroad must take stock of which avenues, if any, are available in their destination country in the event of medical malpractice. Medical malpractice occurs when a medical professional does not meet the standard of care, resulting in a medical error that injures the patient. ${ }^{27}$ Medical error is defined as:

an unintended act (either of omission or commission) or one that does not achieve its intended outcome, the failure of a planned action to be completed as intended (an error of execution), the use of a wrong plan to achieve an aim (an error of planning), or a deviation from the process of care that may or may not cause harm to the patient. 28

In the US, when medical malpractice occurs and results in physical, emotional, or financial injury, domestic patients typically turn to

23. $I d$.

24. See Why Seek Out a JCI-Accredited Hospital, WORLD HOSPITAL SEARCH, https://www.worldhospitalsearch.org/the-value-of-jci-accreditation/why-seek-out-a-jciaccredited-hospital/ (last visited Oct. 13, 2019).

25. JOSEF WOODMAN, PATIENTS BEYOND BORdERS: EVERYONE'S GUIDE TO WORLDCLASS MEDICAL TOURISM 63 (2d ed. 2007).

26. DENNIS S. AGLIANO, REPORT 3 OF THE COUNCIL ON ETHICAL AND JUDICIAL AFFATRS 7 (2018), https://www.ama-assn.org/sites/ama-assn.org/files/corp/media-browser/public/ about-ama/councils/Council\%20Reports/council-on-ethics-and-judicial-affairs/a18-cejareport-3.pdf.

27. Christian Nordqvist, Medical Malpractice: What Does It Involve?, MED. NEWS TODAY, https://www.medicalnewstoday.com/articles/248175.php. (last updated Apr. 5, 2017).

28. Martin A. Makary \& Michael Daniel, Medical Error-The Third Leading Cause of Death in the US, BMJ, May 2016, at 2016;353:i2139. 
medical malpractice lawsuits to recover. ${ }^{29}$ Unfortunately, when malpractice occurs in foreign countries, international patients are often left to navigate unfamiliar legal landscapes on their own. ${ }^{30}$ Moreover, each nation has a unique judicial system, which leads to inconsistent procedures, outcomes, and recoveries.

The International Code of Medical Ethics, adopted by the World Medical Association in 1949, outlines the duties of physicians and requires that all physicians be "dedicated to providing competent medical service . . . with compassion and respect for human dignity." 31 And while JCI works to hold international facilities and their doctors to high standards, some medical tourism destinations are more concerned with profit than with anything else. ${ }^{32}$

International physicians can skimp on their duty of care owed to patients who partake in medical tourism by failing to disclose vital information regarding traveling for surgical procedures. For example, medical tourists with lengthy postoperation flights have a heightened risk of pulmonary embolism, ${ }^{33}$ and perioperative deep vein thrombosis. ${ }^{34}$ Additionally, medical tourists may face greater difficulty in obtaining follow-up care at home after leaving their destination country, ${ }^{35}$ as well as an increased risk of contracting antibiotic-resistant infections, such as Mycobacterium abscessus, Staphylococcus aureus, and Escherichia coli. ${ }^{36}$ When physicians do not explicitly warn patients of these problems, things can go wrong quickly.

29. Nordqvist, supra note 27.

30. See Ambar Mehta et al., Global Trends in Center Accreditation by the Joint Commission International: Growing Patient Implications for International Medical and Surgical Care, 24 J. TRAVEL MED. 1, 3 (2017).

31. INTERNATIONAL CODE OF MEDICAL ETHICS 728 (WORLD MED. ASs'N 1949), reprinted in DIETER GIESEN, INTERNATIONAL MEDICAL MALPRACTICE LAW: A COMPARATIVE LAW STUDY OF CIVIL LIABIITY ARISING FROM MEDICAL CARE (1988).

32. See COHEN, supra note 13 .

33. Kerrie S. Howze, Medical Tourism: Symptom or Cure?, 41 GeoR. L. REv. 1013, 1028 (2007).

34. Lin H. Chen \& Mary E. Wilson, The Globalization of Healtheare: Implications of Medical Tourism for the Infectious Disease Clinician, 57 CLINICAL INFECTIOUS DISEASES 1752, 1757 (2013).

35. Devon M. Herrick, Medical Tourism: Global Competition in Health Care, NAT'L CTR. FOR POL'Y ANALYSIS 25 (Nov. 2007), http://www.recoverdiscover.medretreat.com /templates/UserFiles/Documents/Medical\%20Tourism\%20-\%20NCPA\%20Report.pdf (follow-up care postsurgical procedure can include monitoring the healing process and removal of stitches, among others).

36. Chen \& Wilson, supra note 34 , at $1756-57$. 


\section{Jurisdiction Generally}

"As a moth is drawn to the light, so is a litigant drawn to the United States. If he can only get his case into their courts, he stands to win a fortune." ${ }^{37}$ Lord Denning's famous quote illustrates the fact that many individuals look to the United States if and when legal issues arise. For wronged patients to sue within the United States judiciary, the Constitution requires that a court have personal jurisdiction over the defendant healthcare provider. ${ }^{38}$ When foreign medical tourists experience medical malpractice within the United States, litigation typically results in greater damages awarded to the foreign patient than if they had sued in their home country. ${ }^{39}$ Because the United States already has a well-established system for medical malpractice lawsuits ${ }^{40}$ this section will focus on the problems American patients face in destinations outside of the United States.

In most instances of medical malpractice abroad, American longarm statutes are unlikely to reach foreign healthcare providers to hail them into the US court system unless the healthcare providers "regularly do[ or solicit[ business, engage [ in any other persistent course of conduct in the State or derive] substantial revenue from services, or things used or consumed in the State . ..."41 Many times, even if a long-arm statute reaches, forum non conveniens will typically force the injured party to sue wherever the harm occurred, so long as the country's judicial system will allow for it. ${ }^{42}$ But in the event that a foreign malpractice suit makes its way into American courts, litigants still face an additional barrier to recovery of damages. ${ }^{43}$ "Foreign courts are often 'reluctant to enforce the decisions of US courts,' because '[m]any other countries find some of the grounds for jurisdiction in the

37. Smith Kline \& French Labs. Ltd. v. Bloch [1983] 2 AL ER 72, 74 (Eng.). See generally Clare Dyer, Lord Denning, Controversial 'People's Judge', Dies Aged 100, THE GUARDIAN (Mar. 5, 1999, 10:04 PM), https://www.theguardian.com/uk/1999/ mar/06/claredyer1 (discussing how Lord Denning was one of history's most celebrated judges, widely known for handing down fair judgments with the interests of ordinary people in mind.).

38. See generally Int'l Shoe Co. v. Washington, 326 U.S. 310 (1945) (discussing personal jurisdiction).

39. See COHEN, supra note 13 , at 82 .

40. See generally David A. Hyman, Medical Malpractice and Compensation in Global Perspective: How Does the U.S. Do It?, 87 CHI.-KENT L. REV. 163, 177-92 (2011) (discussing the robust medical malpractice litigation system in the United States).

41. CoHEN, supra note 13, at 83 (quoting DEL. CODE ANN. tit. 10, § 3104 (1999).

42. $I d$. at 85 .

43. Id. at 88 . 
United States exorbitant,' and because 'legal systems that do not include punitive damages may object to large US awards." 44

Medical tourism firms, or private companies that coordinate medical treatment abroad for prospective patients, seem to be attractive defendants for patients seeking to recover after falling victim to medical malpractice. ${ }^{45}$ Firms incorporated within the United States do not present the personal jurisdiction barrier associated with most foreign defendants, and are likely to have deep pockets from which plaintiffs can recover damages. Unfortunately, courts have been reluctant to hold these corporations accountable for the negligence of foreign physicians operating independently of the medical tourism firm, ${ }^{46}$ which makes them less attractive defendants after all.

Because of the lack of viable options in the American court system, many wronged patients who sought medical treatment abroad are forced to litigate their claims in unfamiliar, foreign judicial systems. This is problematic, especially considering patients from the United States seek medical treatment abroad due to lack of resources in the first place. ${ }^{47}$

\section{POLICIES AROUND THE WORLD}

While medical tourism has been regulated economically, very little has been done to protect patient rights, namely a patient's right to recover in the event of adverse outcomes. In order to understand the complexities and shortcomings of this global industry, this section will discuss policies that guide cosmetic procedures in the United States, Brazil, South Korea, and Thailand.

\section{The United States}

When seeking premiere medical care, approximately 40 percent of the world's medical tourists visit the United States for treatment. ${ }^{48}$ Well-known medical institutions, such as the Mayo Clinic, Cleveland

44. Id. (quoting Jenny S. Martinez, Towards an International Judicial System, 56 STAN. L. REV. 429, 511 (2003)). See also Antonio F. Perez, The International Recognition of Judgments: The Debate Between Private and Public Law Solutions, 19 BERKELEY J. INT'L L. 44, 57 (2001) (discussing perceived asymmetry in recognition and enforcement of foreign judgments).

45. See Philip Mirrer-Singer, Note, Medical Malpractice Overseas: The Legal Uncertainty Surrounding Medical Tourism, 70 L. \& CONTEMP. POL. 211, 215-16 (2007).

46. See id. at 216-17.

47. Cf. WOODMAN, supra note 25, at 24-26 (arguing that patients seek medical treatment abroad to minimize costs).

48. Boyd et al., supra note 21 . 
Clinic, and Johns Hopkins, continually attract international patients due to their prestigious reputations. ${ }^{49}$ Looking at how the United States' health care system is viewed, "the U.S. brand of medicine is still perceived as being the most advanced health system" in the world. ${ }^{50} \mathrm{In}$ the twentieth century, medical tourism into the United States was primarily driven by wealthy patients from abroad seeking specialties not available in their home countries. ${ }^{51}$ This continues into the twentyfirst century, as the United States continues to offer state-of-the-art treatments at prices that wealthy travelers can afford. ${ }^{2}$

The United States boasts a whopping 5,534 registered hospitals across the country to date, ${ }^{53}$ as well as countless outpatient facilities maintained specifically for cosmetic procedures. There are over 7,000 plastic surgeons practicing within the United States, ${ }^{54}$ and according to the American Society of Plastic Surgeons (ASPS) "17.5 million surgical and minimally invasive cosmetic procedures [were] performed ... in 2017 . ..."55

In the United States, cosmetic surgery is rarely covered by insurance. Unless a procedure is found to have some sort of greater medical purpose, like surgical reconstruction, patients are forced to pay out of pocket. ${ }^{56}$ For international patients seeking treatment within the US, the out of pocket costs are no different, yet medical tourists still seek treatment in the States. Kher writes, "[e]lective surgeries are key moneymakers for hospitals," so the economic benefits of cosmetic surgeries are clear. ${ }^{57}$ Rodrigo Alves, better known as the "human Ken doll," has had countless elective cosmetic procedures to achieve his idea

49. Allison Van Dusen, U.S. Hospitals Worth the Trip, FoRBES (May 29, 2008, 6:00 PM), https://www.forbes.com/2008/05/25/health-hospitals-care-forbeslife-cx_avd_out sourcing08_0529healthoutsourcing.html\#589215f952e1.

50. Id.

51. CoHEN, supra note 13, at 11.

52. Id. at $11-12$.

53. Fast Facts on US Hospitals, AM. HOSP. ASS'N, https://www.aha.org /system/files/2018-02/2018-aha-hospital-fast-facts.pdf (last updated Feb. 2018).

54. 2017 Plastic Surgery Statistics Report, AM. SOCY OF PLASTIC SURGEONS 3 (2017), https://www.plasticsurgery.org/documents/News/Statistics/2017/plastic-surgery-statisticsfull-report-2017.pdf.

55. New Statistics Reveal the Shape of Plastic Surgery, AM. SOC'Y OF PLASTIC SURGEONS (Mar. 1, 2018), https://www.plasticsurgery.org/news/press-releases/newstatistics-reveal-the-shape-of-plastic-surgery (providing statistics that show that 1.8 million of these cosmetic procedures were surgical in nature, while the other 15.7 million were minimally invasive).

56. See, e.g., Cosmetic Surgery and Procedures, CIGNA, https://www.cigna.com/ individuals-families/health-wellness/hw/medical-topics/cosmetic-surgery-and-proceduresaa64111 (last updated Oct. 5, 2017).

57. Unmesh Kher, Outsourcing Your Heart, in CONTEMPORARY READINGS IN Globalization 143 (Scott R. Sernau ed., 2008). 
of the perfect figure; he has spent over $\$ 800,000$ thus far. ${ }^{58}$ In early 2018, Alves traveled from his home in the United Kingdom to Los Angeles to have four ribs removed to achieve a slimmer waist. ${ }^{59} \mathrm{He}$ was the first patient to undergo this type of cosmetic surgery, despite cautions from physicians that his lung function could be impaired. ${ }^{60}$

When malpractice does occur for medical tourists within the United States, I. Glenn Cohen writes that "medical tourists for whom the United States is the destination country will usually receive a windfall in terms of tort actions, and deficient recovery is less of a concern." 61 While Alves' surgery was completed without error or adverse consequences, recovery of damages would have been relatively simple for him had malpractice occurred. Because the operating physician was a resident of California, Alves could have easily brought and litigated a malpractice suit within the American legal system without fear of significant procedural hardships.

\section{Brazil}

While US health insurance typically does not cover cosmetic procedures unless medically necessary, 62 individuals in Brazil are thought to have a so-called "right to beauty."63 Brazilian plastic surgeon, Dr. Ivo Pitanguy, developed pioneering techniques for breast reductions, tummy tucks, and the famous Brazilian butt lift that have since become standard in the medical field. ${ }^{64}$ Pitanguy went on to open a special surgery wing for low-income patients, which provides plastic and reconstructive surgeries and doubles as a training center for young surgeons. ${ }^{65}$ As part of Dr. Pitanguy's legacy, public hospitals also offer

58. Jon Lockett, Human Ken Doll Has Four Ribs Removed to Get a Slimmer Waist, THE SUN (Jan. 10, 2018, 3:22 PM), https://nypost.com/2018/01/10/human-ken-doll-hasfour-ribs-removed-to-get-a-slimmer-waist/.

59. Id.

60. $I d$.

61. COHEN, supra note 13 , at 82 .

62. CignA, supra note 56.

63. Alvaro Jarrin, The Dark Side of Brazil's "Right to Beauty," QUARTZY (May 3, 2018),

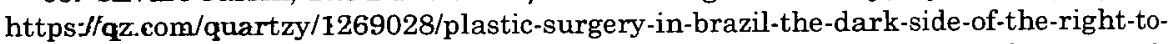
beauty/ (describing how the surgeon rose to fame in the early 1960s after operating on child burn victims near Rio de Janeiro, and the transformative experience led Dr. Pitanguy to the revelation that an individual's appearance is tied to his or her emotional well-being and that the "right to beauty" was just as basic as any other health need).

64. Natasha Singer, Ivo Pitanguay, Plastic Surgeon to the Stars and a Celebrity Himself, Dies at 93, N.Y. TMMES (Aug. 7, 2016), https:/www.nytimes.com/2016/08/08/ obituaries/dr-ivo-pitanguy-pioneering-brazilian-plastic-surgeon-dies-at-93.html.

65. Id. 
free cosmetic procedures as part of Brazil's promise to provide comprehensive healthcare to its people. ${ }^{66}$

In order to understand Brazil's medical tourism industry, we must first understand the complexities of its dual healthcare system. After the fall of the military dictatorship in 1988, Brazil's new constitution encompassed citizens' rights to good health and mandated that the state provide universal access to comprehensive healthcare. ${ }^{67}$ This, in turn, created a dual system of healthcare within the nation: a drastically underfunded public system for the working class and a cutting-edge private system for the wealthy. ${ }^{68}$ Brazil's public healthcare system is plagued with long waiting times and inadequate hospital infrastructure; there are only about two hospital beds for every thousand Brazilians, and patients are forced to wait for months just to get a simple x-ray. 69 An estimated 70 percent of the nation's nearly 200 million people use Brazil's public system, while the rest of the nation is wealthy enough to afford private care, avoiding these challenges. ${ }^{70}$

Medical anthropologist Alvaro Jarrín interviewed multiple Brazilian patients who have obtained subsidized cosmetic procedures at public hospitals. Jarrín observed that, while burn victims and patients with other deformities were once the main beneficiaries of these low-cost procedures, nearly 95 percent of all surgeries at clinics he visited have become "purely aesthetic."71 Jarrín also noted that "most of Brazil's surgical innovations are first tested by plastic surgeons in public hospitals, exposing those [working class] patients to more risks than wealthier patients." 72 Since 1988, state resources have been funneled into these plastic surgery residency programs to ensure innovation, expansion, and continuation..$^{73}$ And since public hospitals serve as training grounds for aspiring plastic surgeons, medical residents perform most cosmetic procedures rather than fully qualified surgeons. ${ }^{74}$ Jarrín notes that Brazilian surgeons in training have a

66. Id (noting that the government subsidizes nearly half a million cosmetic surgeries annually).

67. World Health Organization, Flawed but Fair: Brazil's Health System Reaches Out to the Poor, 86 BULl. WORLD HEALTH ORG. 248, 248 (2008).

68. Jarrin, supra note 63.

69. Olga Khazan, What the U.S. Can Learn from Brazil's Healthcare Mess, THE ATLANTic (May 8, 2014), https://www.theatlantic.com/health/archive/2014/05/the-strugglefor-universal-healthcare/361854/.

70. World Health Organization, supra note 67.

71. Id.

72. $I d$.

73. See Alvaro JarRín, The Biopolitics of BeaUtX: Cosmetic Citizenship and AFFECTIVE CAPITAL IN BRAZIL 61 (2017).

74. Jarrín, supra note 63. 
vested interest in sharpening their skills during strictly cosmetic procedures, as they will later market these skills in private practice. ${ }^{75}$ This creates a complex relationship between the public and private healthcare systems in Brazil, especially concerning cosmetic procedures: medical residents essentially use low-income patients within the public system as test subjects to benefit wealthier individuals who utilize the private system. ${ }^{76}$

A small but significant percentage of patients in Brazil have been left unhappy with their results. ${ }^{77}$ Not only are some patients left with unsightly scarring and infections, surgeons sometimes blur the boundaries between reconstructive and aesthetic procedures to practice highly valuable procedures that will be useful later on in private practice, ${ }^{78}$ or to push the envelope and practice new techniques. ${ }^{79}$ Nowadays, "poor patients must be willing to become experimental subjects to have access to their beauty." 80

Unfortunately, because the Brazilian judicial system is not likely to offer much in terms of damages in the event these problems are litigated, few patients-Brazilian or foreign-turn to the courts. ${ }^{81}$ If Brazilian patients who have been wronged were to take their chances in court litigating a medical malpractice suit, they would still need an expensive expert medical evaluation, which is certainly out of reach for patients who took advantage of the free, public health system. ${ }^{82}$ If foreign patients seek justice through the Brazilian court system, their likelihood of sufficient recovery is often exceptionally low, even for egregious medical errors that lead to the death of a patient. ${ }^{83}$ Further,

75. $I d$.

76. Id. ("[M]any patients declare that they were 'cobaias' (guinea pigs) for the medical residents who would operate on them" in public hospitals.").

77. See JARRÍN, supra note 73, at 156-157 (Jarrín interviewed many patients, but most notably one woman who was left with uneven breasts and misplaced nipples after a breast augmentation in Brazil. She also developed intense infections, which is a sign of the operation taking place in a nonsterile environment. In lieu of suing the operating physicians, the facility offered to redo her surgery for free.). See also Shasta Darlington, Obsession With Beauty Almost Killed Brazilian Pageant Runner-Up, CNN (Feb. 16, 2015, 7:38 AM), https://www.cnn.com/2015/02/15/health/brazil-dangerous-plastic-surgery/index .html ("According to the Federal Council of Medicine, there are 5,500 recognized plastic surgeons in Brazil, but nearly 12,000 doctors perform cosmetic procedures without proper training.").

78. Jarrín, supra note 63.

79. See JARRín, supra note 73 .

80. Id.

81. See Jarrín, supra note 63.

82. See JARRÍN, supra note 73, at 156-57.

83. See id. at 165 ("In the worst-case scenario, where a patient dies and it is proven that the surgeon was at fault, the average award for damages is two hundred thousand 
enforcing a foreign money judgment, in the event that a litigant is victorious, proves to be a steep uphill battle because significant delays often keep money awards tied up for years. ${ }^{84}$ In the last decade, it has become increasingly difficult for litigants, Brazilian and foreign alike, to find an attorney willing to take on claims related to cosmetic surgery in Brazil. ${ }^{85}$ Brazil's legal system requires proof beyond a reasonable doubt. ${ }^{86}$ One Brazilian medical malpractice attorney explained that malpractice claims related to cosmetic surgery rarely succeed because surgeons can easily claim that a patient's harm was the result of common medical complications, rather than surgical error or negligence, and therefore fail to meet the requisite standard of proof. ${ }^{87}$

\section{South Korea}

South Korea boasts medical technology on par with the most advanced countries around the world, ${ }^{88}$ and over the past few decades, South Korea (hereafter Korea) has become a top health travel destination due to its major scientific and technological advancements, as well as the nation's medical tourism market itself. ${ }^{89}$ Korea is teeming with surgical facilities: there are over 500 plastic surgery clinics in Gangnam, an affluent district of Seoul. 90 Busan, the second-largest metropolis after Seoul, is home to over 160 clinics as well as yearly street festivals in which patients can receive consultations on the spot. 91

reais (about sixty thousand U.S. dollars) - a paltry amount given the years of litigation and the exorbitant legal fees that pursuing compensation requires.").

84. See Philip R. Weems, Guidelines for Enforcing Money Judgments Abroad, 21 INT'L BUS. L. 509, 511-12 (1993) (noting that "because Brazil requires a second hearing [i.e., an execution hearing], the expected length of time to enforce a foreign money judgment is about four years").

85. JARRín, supra note 73 , at 164.

86. Id.

87. Id.

88. Jiyun Yu et al., Characteristics of a Medical Tourism Industry: The Case of South Korea, 28 J. TRAVEL \& TOURISM MARKETING 856, 860 (2011).

89. See South Korea, PATIENTS BEYOND BORDERS, https://patientsbeyondborders.com /south-korea (last updated Feb. 19, 2019).

90. Jueun Choi, The Rise of Non-Invasive Plastic Surgeries in South Korea, AL JAZEERA (May 19, 2018), https://www.aljazeera.com/news/asia-pacific/2018/05/rise-invasive-plasticsurgeries-south-korea-180519132009971.html. See also Zara Stone, The K-Pop Plastic Surgery Obsession, THE ATLANTIC (May 24, 2013), https://www.theatlantic.com/ health/archive/2013/05/the-k-pop-plastic-surgery-obsession/276215/ (discussing that while there are large numbers of capable surgeons in Gangnam, many patients choose from a limited number of famous surgeons for their procedures).

91. Sarah Bon, Billion Dollar Industry to be: Plastic Surgery in South Korea, THE RICHEST (Jan. 16, 2014), https://www.therichest.com/expensive-lifestyle/billion-dollarindustry-to-be-plastic-surgery-in-south-korea/. 
With a saturated market for procedures and the movement toward softer and smaller features, an estimated 20 to 30 percent of all women in Seoul have undergone a cosmetic procedure of some sort, while male patients make up around 15 percent of the cosmetic procedure market. ${ }^{92}$

It is not uncommon for cosmetic surgeries such as double-eyelid procedures and facial contouring to cost, in Korea, one-third of the cost in the United States. ${ }^{93}$ Moreover, a "Korean wave" of pop culture has significantly shaped the way many Asians define beauty over the past few decades and has subsequently driven an increasing number of individuals to go under the knife. ${ }^{94} \mathrm{Hallyu}$, the Korean wave, has been sweeping across the globe for years, and has created an entirely new Korean beauty aesthetic. ${ }^{95}$ The trend hints at Caucasian beauty and emphasizes a cute, almost schoolgirl-esque look, complete with tiny features and large, wide eyes. ${ }^{96}$

Koreans aren't the only demographic contributing to the nation's booming medical industry. After the Korean government deemed medical tourism a "top priority" in the mid-2000s, an influx in international patients caused major growth. ${ }^{97}$ In 2006, foreign patients spent around $\$ 50.9$ million on medical procedures in Korea. ${ }^{98}$ In 2013, that number rose to a whopping $\$ 187$ million, and by 2020 revenue from medical tourism is projected to reach nearly $\$ 3.2$ billion. ${ }^{99}$ The attraction to Korea is so strong that, at one point, there was talk of establishing a plastic surgery clinic within a terminal of Seoul's Incheon airport. 100 Most international patients coming to Korea for cosmetic surgery are from China, followed by Japan, southeast Asia, post-Soviet States, Europe, Canada, and the United States. ${ }^{101}$

92. Patricia Marx, About Face: Why Is South Korea the World's Plastic-Surgery Capital?, THE NEW YORKER (Mar. 23, 2015), https://www.newyorker.com/magazine 12015/03/23/about-face.

93. $I d$.

94. Id.

95. See generally Stone, supra note 90 (discussing the rise of noninvasive plastic surgery in South Korea).

96. See Marx, supra note 92; Stone, supra note 89.

97. Yu et al, supra note 88 .

98. $I d$.

99. Bon, supra note 91 .

100. Elise $\mathrm{Hu}$, In Seoul, A Plastic Surgery Capital, Residents Frown on Ads for Cosmetic Procedure, NPR (Feb. 5, 2018, 11:39 AM), https://www.npr.org/sections/parallels/ 2018/02/05/581765974/in-seoul-a-plastic-surgery-capital-residents-frown-on-ads-forcosmetic-procedure (the proposal to place a clinic within Incheon airport was later taken off the table after serious pushback from doctors across South Korea).

101. See, e.g., Simon Mundy, South Korea's Ambitions in Medical Tourism, FIN. TIMES (Oct. 16, 2014), https://www.ft.com/content/b84a4f08-4570-11e4-9b71-00144feabdc0; Scott 
In 2015, the Korean government enacted the Patient Safety Act to promote patient safety and improve medical service quality throughout the nation. ${ }^{102}$ Despite this legislation, very few instances of medical malpractice are reported; according to the Ministry of Health and Welfare, of the 188 institutions that committed medical malpractice in 2017, only 31 notified the Korea Institute for Healthcare Accreditation. ${ }^{103}$ This underreporting of medical malpractice leads to unfair outcomes within Korea: high-profile individuals are quick to be offered compensation, while others are simply ignored. ${ }^{104}$ Moreover, courts in Korea tend to be extremely deferential to the medical profession, ${ }^{105}$ which can lead to disparate and unjust outcomes for litigants. Similarly, recent media exposure of medical error coverups in hospitals has led the public to generally distrust the Korean medical profession and may discourage wronged patients from attempting litigation in the first place. 106

Korea's civil law system for torts, including medical malpractice, presents numerous other hurdles beyond mere distrust of the system. Though Korean law mandates that compensation for victims of medical malpractice be equal to the cost of the botched procedure, juries do not award additional damages to these victims even if medical errors cost patients more than the price of the procedure. ${ }^{107}$ While damages in Korea are calculated by considering the actual damages suffered, consequential costs for care resulting from the injury, and pain and suffering, the final figure is far less than the average amount of damages awarded in the United States in similar cases. ${ }^{108}$ Moreover, unlike in the United States, litigants are not afforded the privilege of deposing expert witnesses or subpoenaing documents. ${ }^{109}$ The Korean legal system also requires that plaintiffs prove their complaints beyond

Swan, Korea Becoming a Global Center for Plastic Surgery, WTHR (Feb. 16, 2018, 6:33

AM), https://www.wthr.com/article/korea-becoming-a-global-center-for-plastic-surgery.

102. Patient Safety Act, Act No.13113, Jan. 28, 2015, art. 1 (S. Kor.).

103. Hyunsu Yim, Botched Surgery Sparks Debate Over Medical Malpractice, THE KOREA BIZWIRE (Apr. 25, 2018), http://koreabizwire.com/botched-surgery-sparks-debateover-medical-malpractice/117900.

104. See id.

105. James Yeongjun Park, The Current State of Medical Error in South Korea, 1 SCHOLAR J. APPLIED SCI. RES. 28, 31 (2018).

106. See id. at 32.

107. See Sanghan Wang \& John Zen Jackson, The Handling of Medical Malpractice in South Korea as a Stimulus for American Tort Reform Action, 2014 FOR THE DEF. 18, 20.

108. Id. ("Pain and suffering [awards] . . . are often minimal amounts. The low awards partially result from the use of a table of money damages, which a judge turns to in a civil proceeding for guidance.").

109. Id. 
a reasonable doubt in both civil and criminal litigation, ${ }^{110}$ which is an incredibly tough standard to meet, made even harder for foreign litigants. Finally, courts are unlikely to impose consequences on medical professionals, even though the law states that " [o]ccupational or gross negligence' that causes death or injury is subject to punishment by either imprisonment of not more than five years or by a fine not exceeding 20 million Won (approximately $\$ 20,000$ )." ${ }^{111}$

\section{Thailand}

Thailand has long been at the forefront of the medical tourism industry. As early as the $1970 \mathrm{~s}$, Thailand became a popular destination for medical procedures because of its specialization in gender confirmation surgeries and, in later years, the broader realm of cosmetic surgery. ${ }^{112}$ Though the nation was already considered a popular tourist destination for travelers on holiday, Thailand's medical reputation only bolstered the number of individuals visiting the nation. ${ }^{113}$ In the early 2000 s, the Thai government formally recognized the nation as a medical destination, subsequently causing significant growth within the nation's medical tourism sector. ${ }^{114}$ In 2014, for example, 900,000 of Bangkok's 16 million visitors sought medical treatment within the city. ${ }^{115}$ In 2017, over 2.4 million medical tourists visited Thai hospitals for services including cosmetic surgery, dental procedures, and fertility treatment. ${ }^{116}$ Aside from state-of-the-art private healthcare facilities, medical tourists are drawn to Thailand for low-cost procedures, as procedures in Thailand typically cost around 20 to 25 percent as much as those in the United States. ${ }^{117}$

The nation's universal healthcare system must first be analyzed to understand the ways in which medical tourism is simultaneously helping and harming Thailand. In 2001, the Thai government introduced the Universal Coverage Scheme (UCS), a program meant to provide outpatient, inpatient, and emergency care to all Thai citizens,

110. Id. at 19.

111. Id.

112. John Connell, Medical Tourism: Sea, Sun, Sand and . . Surgery, 27 TouRISM MGMT. 1093, 1095 (2006).

113. Wongkit \& McKercher, supra note 4, at 15.

114. Id.

115. Steve Finch, Thailand Top Destination for Medical Tourists, 186 CMAJ E1, E1 (2014).

116. See K-Research: Foreigners Key for Hospitals, BANGKOK POST (Jume 13, 2018, 4:00 $\mathrm{PM}$, https://www.bangkokpost.com/business/news/1483849/k-research-foreigners-key-forhospitals.

117. Kher, supra note 57. 
according to need. ${ }^{118}$ By 2011, the UCS covered 98 percent of the Thai population. 119 Unfortunately, federally funded healthcare in Thailand does not offer the same quality of care as the private system. In many rural or developing regions, healthcare is simply inaccessible to many individuals. ${ }^{120}$ Moreover, healthcare in rural areas is often administered by poorly trained physicians as opposed to those working in private facilities. ${ }^{121}$ And while the UCS allowed for the Thai government to financially incentivize physicians to work in "unpopular rural areas," 122 it could not keep up with the growing sector of medical tourism and the problem it was creating: Thailand's entire public healthcare system is now facing a shortage of medical professionals. ${ }^{123}$

Though millions of patients flock to Thailand each year for medical procedures, this economic growth happens at the expense of Thai citizens. Bumrungrad International Hospital, a massive private hospital in Bangkok, has been praised as the "world's first truly global hospital," 124 and was the first healthcare facility in Asia to receive JCI accreditation in 2002. ${ }^{225}$ Hamilton writes, "[w] hen medical tourists come to Bangkok, they usually go to places like Bumrungrad Hospital. It's a private facility, downtown ... It has a sushi bar, interpreters . . . and VIP suites with marble bathrooms." 126 Unsurprisingly, most Thai citizens cannot afford care at Bumrungrad.127 Furthermore, the international hospital does not explicitly list as acceptable any federally funded health insurance provided by the UCS.128 Instead of Bumrungrad, many Thai nationals head to hospitals like Siriraj Hospital, where hundreds of patients crowd into halls and waiting

118. Sue George, What Thailand Can Teach the World About Universal Healthcare, THE GUARDIAN (May 24, 2016), https://www.theguardian.com/health-revolution/2016/may/24/ thailand-universal-healthcare-ucs-patients-government-political.

119. Id.

120. See id.

121. See id.

122. $I d$.

123. See id.; Jon Hamilton, Medical Tourism Creates Thai Doctor Shortage, NPR (Nov. 29, 2007, 12:06 PM), https://www.npr.org/templates/story/story.php?storyId=I6735157.

124. Healthy TRavel Media, Patients Beyond BORDERS FoCUS ON: BUMrungrad INTERNATIONAL HOSPITAL 5 (2011).

125. Id.; see also Finch, supra note 115 (explaining that Bumrungrad is one of the largest private hospitals in Southeast Asia and is a popular destination for medical tourists).

126. Id.

127. Id.

128. See Insurance: What Do We Accept?, BUMRUNGRAD INT'L HOSP., https://www.bumrungrad.com/en/plan-your-visit/insurance-what-we-accept\#Thailand InsuranceDirectBilling (last visited Nov. 30, 2018). 
rooms awaiting free medical care. ${ }^{129}$ Though Siriraj treats over 2 million patients every year, low-income Thai citizens often wait for hours to be seen by a physician for less than five minutes. ${ }^{130}$ And though Thai physicians trained at public universities must spend a minimum of three years working at state-run hospitals upon graduation, ${ }^{131}$ the combination of being overworked and underpaid drives providers to private hospitals once they have fulfilled their commitment, ${ }^{132}$ which in turn disadvantages Thai citizens. ${ }^{124}$

Private Thai hospitals offer cosmetic procedures to medical tourists at comparatively low costs. A facelift, for example, can cost anywhere from $\$ 10,500$ to $\$ 16,000$ in the United States, but only a mere $\$ 5,000$ plus airfare in Thailand. ${ }^{133}$ Significant cost savings can make traveling to Thailand for surgical procedures worth it, but medical tourists should be wary of the Thai judicial system in the event their surgeries go south. James Goldberg, the father of a patient who died after a procedure in Thailand, says that Thai police failed to investigate his claims of medical malpractice for litigation purposes, and even if they had, it would have been nearly impossible to secure a Thai attorney to represent him in Thai court. ${ }^{134}$ Goldberg notes that "[n]o attorney in Thailand will take up a case on contingency. . . [and] you have to pay the lawyers up front, with very little chance of winning." 135 Additionally, because police in Thailand have little medical knowledge, they rely on the Thai Medical Council to determine whether they should prosecute. ${ }^{136}$ Unfortunately, the Council is made up of representatives from Thailand's healthcare sector, which disincentivizes the Council from making formal suggestions to prosecute their colleagues. ${ }^{137}$

In the event that a medical tourist secures legal representation to bring a malpractice suit in Thai court, the tourist is likely to face additional hurdles. First, the most important evidence within a medical malpractice suit is the testimony of another Thai physician agreeing

129. See Hamilton, supra note 123.

130. Id.

131. See Noah Leavitt, Thailand Seeks to Address Shortage of Rural Health Care Providers, HARV. SCH. OF PUB. HEALTH (May 11, 2015), https://www.hsph.harvard.edu /news/features/thailand-seeks-to-address-shortage-of-rural-health-care-providers/.

132. See Hamilton, supra note 123.

133. See WOODMAN, supra note 25 , at 10.

134. Jonathan Head, The Dark Side of Cosmetic Surgery in Thailand, BBC NEWs (Mar. 17, 2015), https://www.bbc.com/news/business-31433890.

135. Id.

136. Id.

137. See id. 
that the doctor acted negligently or unlawfully to cause injury. ${ }^{138}$ As previously shown through the Thai Medical Council's low likelihood of self-reporting, most Thai physicians are reluctant to offer damning testimony against their colleagues. Additionally, damages awarded in medical malpractice suits in Thailand differ dramatically from those awarded in western court systems: punitive damages and damages for disfigurement or pain and suffering are not awarded by Thai courts, making the awards for successful plaintiffs in Thailand far lower than in other nations. 139

\section{JCI-ACCREDITATION AND THE AUTOMATIC ESTABLISHMENT of PERSONAL JURISDICTION IN THE UNITED STATES}

Thus far, this note has analyzed the state of medical tourism and various obstacles for bringing medical malpractice cases in multiple nations around the world. This section focuses on finding a solution for American litigants seeking to recover against foreign healthcare providers, though similar challenges are faced by medical tourists across the globe. Due to dramatic variations in judicial systems worldwide, this note will advocate for US courts to establish personal jurisdiction over foreign physicians operating in JCI-accredited facilities. Additionally, this note will propose changes to JCI to allow wronged foreign patients to appeal to JCI directly rather than litigating medical malpractice claims in foreign courts on their own.

\section{Establishment of Personal Jurisdiction Within the US over JCI-Accredited Providers}

As this note has highlighted, significant legal gaps still remain surrounding medical malpractice litigation in the international community. These inconsistencies can lead to an inequitable administration of justice depending on which nation a litigant is forced to sue in, as well as discourage individuals from pursuing litigation in a foreign country due to cost, inconvenience, and the unlikeliness of a satisfactory outcome. In order to remedy these issues, JCI should establish personal jurisdiction in US courts over all of their accredited healthcare facilities abroad.

138. Siriporn Denkesineelam, Medical Malpractice in Thailand, SIAM LEGAL INT'L, https://www.hg.org/legal-articles/medical-malpractice-in-thailand-19239 (last visited Nov. $30,2018)$.

139. $I d$. 
Because JCI is an American organization that holds their accredited international healthcare providers to the same rigorous standards as US providers, it would be reasonable to hold international healthcare providers similarly accountable in cases of medical malpractice. ${ }^{140}$ When a doctor commits medical malpractice against a US citizen within the United States, American litigants automatically have a foot in the door to the American court system if the defendant has purposefully established minimum contacts. ${ }^{141}$ But when a doctor commits medical malpractice against a US citizen abroad, American medical tourists are often unable to establish personal jurisdiction over the healthcare professionals that have harmed them.142 JCI accreditation of an international healthcare provider should be enough to establish the provider's minimum contacts with the United States, ${ }^{143}$ and more specifically with Illinois, where JCI is headquartered. ${ }^{144}$

The idea that a single contact is enough to establish ties to the forum state is known as minimum contacts. This idea was established in the International Shoe decision, where the Supreme Court held that a court may exercise jurisdiction over a defendant if they have "certain minimum contacts with [the forum state] such that the maintenance of the suit does not offend 'traditional notions of fair play and substantial justice." 145 In a situation in which medical malpractice occurs within a foreign country at a hospital accredited by JCI, courts should view a foreign hospital's connection to Illinois through JCI accreditation as sufficient to establish specific jurisdiction over the foreign provider in Illinois federal courts to bolster patients' rights.

While opponents of this proposition may be concerned about a flood of litigation brought in federal courts, ${ }^{146}$ specifically, those courts sitting

140. See WOODMAN, supra note 25 , at 63.

141. See Burger King v. Rudzewicz, 471 U.S. 462 (1985) (discussing personal jurisdiction established through contractual agreements). See generally Int'l Shoe Co. v. Washington, 326 U.S. 310 (1945) (discussing the establishment of personal jurisdiction).

142. See id.

143. See generally Intl Shoe Co., 326 U.S. 310 (discussing the due process requirement of having minimum contacts within a forum).

144. Contact Us, JOINT COMMISSION INT'L, https://www.jointcommissioninternational. org/contact-us/contact-jci/ (last visited Dec. 1, 2018) (JCI is headquartered at 1515 West 22nd Street, Oakbrook, Illinois, USA).

145. See Int'l Shoe Co. 326 U.S. at 316 (1945) (durisdiction may be exercised if the defendant has "certain minimum contacts with [the forum state] such that the maintenance of the suit does not offend traditional notions of fair play and substantial justice.").

146. See generally Marin K. Levy, Judging the Flood of Litigation, 80 U. CHI. L. REv. 1007 (2013) (discussing judicial and legislative decisions that would lead to "opening the floodgates of litigation" in federal court, thus disturbing the balance of power between state and federal court systems). 
in Illinois, this concern must be weighed against the protection of patient rights, including the right to sue physicians for medical malpractice. The various policies around the world concerning medical malpractice litigation are insufficient to protect patients and allow them to recover in the event of significant harm. The United States has a vested interest in protecting its citizens as well as holding international healthcare providers accountable for bad actions directed towards Americans. Medical tourism is a globalized market growing larger each year, ${ }^{147}$ and though nations may regulate it economically, the United States should be the first to lead the charge in regulating the legal side of medical tourism by extending personal jurisdiction over JCI accredited foreign facilities.

\section{Advantages for Patients}

Since medical malpractice during cosmetic procedures can result in outcomes ranging from unsatisfactory aesthetic results to death, the damages that litigants seek vary accordingly. ${ }^{148}$ Restrictions on American patients' ability to litigate medical malpractice claims in foreign courts limit their ability to recover. And because these restrictions vary widely depending on the country in which an incident occurs, foreign courts provide American litigants with judgments that are inconsistent at best.

In the United States, courts take medical malpractice claims seriously. Although years of tort reform have led some state legislatures to enact limits, or "caps," on the amount of damages a litigant can recover, these caps vary in amount from $\$ 250,000$ to upwards of $\$ 2.25$ million. ${ }^{149}$ However, in popular destination countries for medical tourism, damages awarded to successful litigants in medical malpractice suits are almost always lower than damages awarded in US courts. ${ }^{150}$

When discussing patient rights and the right to recover in the event of malpractice abroad, American patients are most protected when given the opportunity to litigate malpractice claims at home. Not only might the establishment of personal jurisdiction within the United

147. See Dalen \& Alpert, supra note 11, at 9 (explaining that the overall number of medical tourists worldwide was estimated to be somewhere between 14 and 16 million in 2017 and is expected to grow in the coming years).

148. See SBWire, Medical Malpractice and Cosmetic Surgery, DigiTaL J. (Nov. 19, 2018), http://www.digitaljournal.com/pr/4033128.

149. See David Goguen, Award (And Settlement) Limits in a Medical Malpractice Case, ALLLAW, https://www.alllaw.com/articles/nolo/medical-malpractice/award-settlementlimits.html (last visited Dec. 2, 2018).

150. E.g., JARRfN, supra note 73, at 165; Wang \& Jackson, supra note 108; Denkesineelam, supra note 140 . 
States over foreign, JCI accredited healthcare providers lead to consistency, and subsequently more equitable administrations of justice in medical malpractice suits, wronged patients may recover sufficient damages for their injuries to help restore their pre-surgical condition. American litigants may also be more likely to view the outcomes of medical malpractice suits brought in the US as satisfactory, as opposed to outcomes of litigation abroad, thus increasing the legitimacy of the US judiciary.

Finally, allowing Americans to bring claims against international healthcare providers in the US court system will be more convenient than forcing litigants to sue abroad. By establishing personal jurisdiction over international healthcare providers within the United States, Americans will enjoy massive cost-savings throughout litigation by foregoing expenses on international travel and lodging. Though Illinois, the state in which JCI is headquartered, may not be the most convenient forum for all individuals wishing to bring medical malpractice claims against a foreign actor, the price of litigating a suit in another state, as opposed to another country entirely, will likely be significantly less costly.

\section{JCI as Appeals Board}

While the establishment of personal jurisdiction within the United States over foreign, JCI accredited healthcare providers may be too radical a solution for now, a small but significant first step in that direction would be the creation of an additional JCI function allowing JCI to serve as an appeals board for medical malpractice claims. Some medical tourists, having experienced medical malpractice firsthand, complain that the JCI accreditation does little for patients because JCI does not get involved in allegations of medical malpractice. ${ }^{151}$

If JCI had the ability to act as an appeals board for medical malpractice claims that occur at JCI accredited facilities, JCI could take on a significant portion of the burden litigants currently bear in considering a lawsuit abroad by investigating claims, inspecting hospitals, and issuing fines to offending providers that will, in turn, be passed along to wronged patients. JCI, acting as an appeals board, could allow patients to recover from offending providers, even if it is not nearly as much as what would be awarded if a claim was successfully brought in either US or foreign courts. The appeals board solution may also save patients the expense of bringing an unsuccessful claim in a foreign court in the event the JCI investigation proved the claim to be

151. See Head, supra note 134. 
unfounded, or could potentially serve an evidentiary purpose in the event litigation went forward within a foreign country.

\section{CONCLUSION}

The effects of medical tourism are felt around the world. While the growing medical tourism market offers significant benefits to patients and nations alike, the market is not without its complications. Nations around the world have begun to address some problems (such as patient safety) through legislation and increased monitoring, but little has been done to tackle the growing concern surrounding medical malpractice litigation. With the rising cost of healthcare in the United States, it is doubtless that Americans will continue to seek medical care abroad at lower costs. Further, without the establishment of personal jurisdiction in the United States over JCI accredited foreign healthcare providers, American medical tourists will continue to suffer due to insufficient avenues that can be utilized in the event of medical malpractice. As the global medical tourism sector continues to evolve, the United States should lead the way in developing policies that protect patients and provide for equitable outcomes. 